\title{
THE EFFECT OF CLINICAL TEACHING METHOD AND LEARNING STYLE ON CLINICAL NURSING LEARNING OUTCOMES
}

\author{
Ida Zuhroidah ${ }^{1 *}$, Nurul Huda ${ }^{1}$, Bagus Dwi Cahyono ${ }^{1}$ \\ ${ }^{1}$ Jember University, Pasuruan Campus \\ *Correspondence: \\ Ida Zuhroidah \\ Email: ida.akper@unej.ac.id \\ Address: Jember University, Pasuruan Campus, Jl. KH. Mansyur No.207, Tembokrejo, Kec. Purworejo, \\ Pasuruan City, East Java Province 67118
}

\begin{abstract}
Background: Nursing Academy of Pasuruan has used problem solving method for learning clinical nursing practice. However, there is obstacle in the implementation of the method due to wide variation in implementing the method among field instructors. Theoretically, bedside teaching method can be used for learning activities to improve learning outcomes. Theoretically, students' learning style is associated with learning outcomes.

Objective: This study aimed to examine the effect of clinical bedside teaching method and learning style of students on clinical practice outcome among nursing students at the Academy of Nursing.

Method: The research method used Quasi-Experimental. The population source was students at the Academy of Nursing, Pasuruan. A sample of 80 students were selected by simple random sampling. Problem solving was used as a comparison method. The data were collected using standard questionnaires, and analyzed by multiple linear regression model.

Result: Results indicated that bedside teaching resulted in higher clinical nursing learning outcome than problem solving method $(b=3.5$, $p<0.001$, CI 95\% 2.6 to 4.4). There was no statistically significant effect of learning styles on learning outcomes of nursing clinical practice $(p>0.05)$.

Conclusion: This study concludes that bedside teaching method results in better clinical nursing learning outcome than problem solving method. It is recommended that all faculty members use bedside teaching as the learning strategy to improve learning outcomes in clinical practice.

Key words: Bedside Teaching, Problem Solving, Learning Styles, Clinical Practical Learning Outcomes.
\end{abstract}

\section{INTRODUCTION}

The implementation of Nursing Vocational Program must be based on national education goals, principles, morals, ethics in sciences, and social interest. It also includes personal interest, ability and initiative. Coherent with the description above, the curriculum nationally applied for the program consists of General Subjects also contains courses based on scientific groups covering basic saints and basic biomedicine, Humaniores, fundamental of nursing, clinical nursing saints, and community nursing saints along with any kinds of learning experiences including classical system, practicum, and clinical practice.

Learning experience in nursing clinics is implemented in health service or real nursing experience. It is implemented especially in qualified hospital, aiming to build good behaviors and skill in professional nursing. Clinical learning process gives chance for nursing students 
applying sciences and skill they earned. Consequently, they will likely behave and be able to do scientific nursing independently and professionally (Husin, 2003).

The students' success in learning experience depends on some factors. These are clinical instructor, instructing process, instructing methods used by the instructors, facilities, and cooperation between clients and families (Nurrahmah 2003). The clinical instructing methods by Reilly and Obermann are experience, problem solution, conference, observation, bedside teaching, and nursing round. Nevertheless, the implementations vary and tend to be generalized for all students without paying attention to their characteristics.

The effectiveness of learning (instructing) activity is affected by student's characteristics, especially cognitive characteristics (Keefe, 1987 in Zepeda and Mayers, 2013). Along with Pirolli and Russel (1990) in Andriessen et al (2013), students' learning methods support learning process by using certain methods. Thus, there is an effect due to cognitive style and learning results.

There are some problems and obstacles in nursing clinical learning process. They are caused by some factors, such as instructing lecturer from institution, field instructor, and students. In advisory process, the lecturer and clinical instructor have the various methods, either in ability or selection. They generally do not see characteristics of students. The students get the problem too. They get difficulty to apply nursing instructions. The factors behind them are intellectual ability, less interpersonal ability, and less technical ability (Suherman, 2009).

Nursing Academy of Pasuruan City Government uses problem solving methods in nursing clinical learning. Based on the evaluation of clinical learning result in Nursing Academy of Pasuruan City Government, in 2011/2012 there were 3 students getting $\mathrm{E}$ for clinical practice score. While in 2012/2013 there were 8 students who got $\mathrm{E}$. In the following year, 2013/2014 6 students got E. Therefore, in 2016, 16 students failed and retook the clinical learning subject. The failed students increase year by year.

Seeing the goals and problems in nursing clinical process, the role of lecturer and clinical instructor determines its success. In order to achieve real learning experience for students, the clinical instructor must select the methods that are proper to students' characteristics.

From the explanation above, the researchers are interested in analyze the effects of instructing methods and learning methods for students' clinical learning results.

\section{METHODS}

Study Design

This research used QuasiExperimental method.

\section{Setting}

This research was conducted at the Academy of Nursing, Pasuruan.

\section{Research Subject}

Sampling in this study was conducted by simple random sampling. The samples size in this research were 80 students of the Academy of Nursing, Pasuruan. Afterward, the researcher conducted a randomization to determine the experimental group (bedside teaching) consisted of 40 students and the control group (problem solving) consisted of 40 students.

\section{Instruments}

The experimental group and the control group were given learning style tests on the research subjects namely visual, auditory and kinesthetic learning style tests. The experimental group was given learning activities with the bedside teaching method on nursing clinical practice. The control group was given problem solving method of nursing clinical practice carried out 3 
times with a time allocation of $2 \times 60$ minutes. They conducted a posttest using observation sheets of clinical skills from institutions that have been according to the nursing standards made by the nursing professional organization, that is Indonesian National Nurses Association (PPNI). Knowledge of nursing care according to NANDA.

The data were collected using standard questionnaires. Learning style variables uses instruments, that is questionnaires compiled by De Porter et al (2010). Learning style variables consist of 3 parts. Part A contains questions related to visuals. Part B contains questions related to auditory, and Part $\mathrm{C}$ contains questions related to kinesthetic. Each question consists of 12 questions, while measurement options are often, sometimes and rarely used. Option results are often multiplied by 2 , sometimes multiplied by 1 and rarely multiplied by 0 . Total results are summed and the large results are the conclusions of the student's learning style.

\section{Data Analysis}

The influence of the guidance method and learning style on the results of clinical nursing practice learning in Nursing Academy of Pasuruan City Government uses multiple linear regression analysis (Murti, 2010) as follows:

$$
\mathrm{Y}=\mathrm{a}+\mathrm{b} 1 \mathrm{X} 1+\mathrm{b} 2 \mathrm{X} 2
$$

Information:

$\mathrm{Y}=$ clinical learning outcomes (score)

$\mathrm{a}=$ constant

$\mathrm{b}=$ regression coefficient

$\mathrm{X} 1=$ learning method $(0=$ problem

solving; 1 = bedside teaching)

$\mathrm{X} 2=$ student learning style $(0=$ visual; $1=$ auditial; 2 = kinesthetic)

Before carrying out multiple linear regression analysis, the assumptions of regression analysis were tested including normality of dependent and independent variables, autocorrelation, linearity, heteroscedasticity, multicollinearity test.

\section{Ethical Consideration}

This research implemented based by permit letter number 800/Akper/163/423.104.10/2017.

\section{RESULTS}

The normality of this research was tested using Kolomogorov-Smirnov and with significance value $>.05$ and SkewnessKurtosis coefficient with significance value between -1.96 to +1.96 . The results found that normal distribution of Clinical Teaching Method, Learning Style, and Clinical Nursing Learning Outcomes. Autocorrelation can be known through Durbin Watson value between 1.5-2.5 denotes no autocorrelation. The results of Durbin Watson value of this study equal to 1.717, it indicates no autocorrelation. Tolerance values for collinearity statistics for all should be greater than 0.10 and the Variance Inflation Factor (VIF) value is less than 10, which means there is no multicollinearity among the predictors. The results for collinearity statistics found that all of variables had correlation coefficient greater than 0.10 . Linearity test uses statistics and scatterplots. Based on the second test, it was found that all significant variables for linearity and scatterplot from the residual standard regression were in the same straight line, so that the assumptions of linearity and homoscedasticity were fulfilled. 
The Effect of Clinical Teaching Method and Learning Style on Clinical Nursing Learning Outcomes by using Multiple Linear Regression

Table 1. Examination of the effect of clinical teaching methods and learning style on clinical nursing outcomes by using multiple linear regression $(n=80)$.

\begin{tabular}{|c|c|c|c|c|}
\hline \multirow[t]{2}{*}{ Variable } & \multirow{2}{*}{$\begin{array}{l}\text { Coefisient } \\
\text { regression } \\
\text { (b) }\end{array}$} & \multirow[t]{2}{*}{$p$} & \multicolumn{2}{|c|}{$\begin{array}{c}\text { Confidence Inteval } \\
95 \%\end{array}$} \\
\hline & & & Lower & Upper \\
\hline Constant & 77.2 & $<0.001$ & 76.5 & 77.9 \\
\hline $\begin{array}{l}\text { Bedside } \\
\text { teaching }\end{array}$ & 3.5 & $<0.001$ & 2.6 & 4.4 \\
\hline Auditory & 0.6 & 0.400 & -0.9 & 2.1 \\
\hline Kinesthetic & 0.2 & 0.657 & -0.8 & 1.3 \\
\hline \multicolumn{5}{|c|}{$\begin{array}{c}\text { N Observation }=80 \\
\text { Adjusted R2 }=44.8 \% \\
\mathrm{p}=<0.001\end{array}$} \\
\hline
\end{tabular}

Source: Primary data of questionnaire, 2017

Table 1 shows the effect of bedside teaching method compared to problem solving method for clinical practical learning result. The students who used bedside teaching had 3.5 points higher than using problem solving. The effects of bedside teaching method appear after controlling the effects of students' learning styles. $(\mathrm{b}=3.5 ; p<0.001$; CI $95 \% 2.6$ to 4.4). And also, the results found that no effect of students learning style toward result of clinical learning practice $(p>$ $0.05)$.

\section{DISCUSSION}

In the analysis result, the students using bedside teaching method got 3.5 units higher than those who used problem solving method. It is appropriate to the hypothesis telling that there is an impact of clinical instructing method and learning style toward the result of clinical learning process significantly and statistically $(p<$ 0.001). Bedside teaching is a method applied on side of client's bed by analyzing client based on their needs (Nursalam dan Efendi, 2008). The advantage of bedside teaching method is that clinical instructor can teach the students to achieve procedural skills, build professional manners, learn biological/ physical development, and communicate directly (Nursalam, 2011).

In bedside teaching method, if the students find new cases, the instructor should explain them of what acts taken, such as analysis and nursing plan. The instructor needs to demonstrate to the students, and the students have chances to practice what they get from the instructor. Moreover, the students also have chance to practice procedural skill technique under the instructor advisory. The skills are stopping bleeding, and applying drops. The instructors are available to be asked anytime during the process, so that the students feel appreciated. Based on the research by Sujarwadi (2005), bedside teaching method is effective to increase knowledge and manners of the students in their duties.

Meanwhile, auditory learning style has 0.6 points higher than visual learning style. The difference is not statistically significant $(p=0.400)$. The students who use kinesthetic learning style have 0.2 points higher than visual method. The difference is not statistically significant $(p=0.657)$. The learning styles of everyone are relatively consistent. Every learner has their own style in earning the information, way of thinking, way of storing, and problem solving. Thus, the cognitive style (learning style) is one the learners' characteristics. Cognitive style and learning quality correlate each other in achieving learning goals, instructional goals or learning results.

De Porter et.al (2010) advise that the teachers treat the learners based on their ability and learning styles, so that the learners can learn conveniently. The result of analysis using bedside teaching is able to increase the result of clinical nursing learning process compared to problem solving method $(p<0.001)$. The advantages of bedside teaching are that the students get the case properly (the case is suitable with the case they previously learned), the 
students do procedural technical skills under the supervision or instructor, and they are able to be independently skillful without instructor's presence. Learning is process of constructing understanding toward the places we live. Students construct knowledge in their own minds (Suparno, 2001). Knowledge construction means that knowledge is not perceived passively, but actively. Knowledge construction of students toward nursing concepts is obtained by reflection for physical environment and mental activities of students.

Other factors affecting learning result in nursing clinics are not only from cognitive aspect but also comprehensive aspect. In applying nursing care, nurse must have cognitive, affective and technical ability. They are affected by internal factors such as motivation and manners of students. They affect the result of learning process in clinical nursing, but not all students have personal idea toward their choice.

\section{CONCLUSION}

This research shows that there are some effects of bedside teaching method for clinical nursing learning result in students of Nursing Academy. The effect is statistically significant $(b=3.5 ; p<0.001$; CI $95 \% 2.6$ to 4.4 ). There is no effect of learning styles toward learning result of clinical nursing $(p>0.005)$.

\section{SUGGESTIONS}

Nursing institution may develop model or learning strategy which applicable in real situation in profession. The strategies can be in workshop and seminar related to developing learning process.

\section{ACKNOWLEDGMENT}

Thank you to all respondents and those who have helped in completing this research until the compilation of this manuscript.

\section{DECLARATION OF CONFLICTING INTEREST}

None.

\section{FUNDING}

The funds used in this study came from the researchers' personal funds.

\section{AUTHOR CONTRIBUTION}

Ida Zuhroidah: Conduct research and compile manuscripts.

Nurul Huda: Conduct research.

Bagus Dwi Cahyono: Conduct research.

\section{ORCID}

Ida Zuhroidah

https://orcid.org/0000-0002-4544-0099

Nurul Huda

https://orcid.org/0000-0003-0734-5098

Bagus Dwi Cahyono

https://orcid.org/0000-0001-5819-6219

\section{REFERENCES}

(2008). Metodologi Riset Epidemiologi. Modul dalam Mengajar di Program Magister Kedokteran Keluarga/ Magister Gizi. Universitas Sebelas Maret.

Anglin, G. J. (2010). Instructional Technology: Past, Present ang Future Third Edition. Englewood: Libraries Unlimited.

Carpenito, L. J. (2009). Nursing Care Plans and Documentation: nursing diagnoses and collaborative problems 5th ed. Philadelphia: JB. Lippincott Company.

Depkes RI. (2006). Kurikulum Nasional Pendidikan Diploma III Keperawatan di Indonesia. Jakarta: Depkes RI.

De Porter, B., Reardon, M., Nourie, L. (2010). Quantum Teaching. Bandung: Mizan Pustaka. 
De Porter, B., and Hernacki, M. (2009). Quantum Learning. Bandung: Mizan Pustaka.

Dryden, G., and Jeanete, V. (2001). Revolusi Cara Belajar. Bandung: Kaifa.

Huda, M. (2010). Pengaruh Metode Bedside Teaching Pemasangan Infus Terhadap Pengetahuan, Keterampilan Dan Sikap Mahasiswa Keperawatan Di Rumah Sakit Umum Daerah Kabupaten Madiun. Tesis tidak diterbitkan. Surakarta: Magister Kedokteran Keluarga Pascasarjana Universitas Sebelas Maret.

Husin. (2003). Fasilitas Pelayanan Kesehatan Pada Pendidikan Tinggi Keperawatan. Makalah disajikan dalam Seminar Fasilitas Pelayanan Kesehatan Dalam Upaya Peningkatan Pendidikan Kesehatan. Lumajang, 5 April.

Holstein, H. (1986). Murid Belajar Mandiri. Bandung: Remaja Karya.

Jacobs, G. M., Lee G. S., and Ball, J. (1996). Learning Cooperative Learning Via Cooperative Learning. Singapura: SEAMEO Regional Language Centre Singapura.

Keliat, B. A. (2002). Metode Bimbingan Klinik Keperawatan. Makalah disajikan dalam Pelatihan Bimbingan Klinik Keperawatan Profesional Jiwa dan Komunikasi Efektif dalam Bimbingan Klinik Keperawatan. Lawang Malang. RSJP Lawang dan PSIK Unibraw. 8-14 Februari.

Murti, B. (2010). Desain dan Ukuran Sampel Untuk Penelitian Kuantitatif dan Kualitatif di Bidang Kesehatan. Yogyakarta: Gadjah Mada University Press.

Nasution, S. (2011). Berbagai Pendekatan dalam Proses Belajar dan Mengajar. Jakarta: Bumi Aksara.

Notoatmodjo, S. (2007). Pendidikan dan Perilaku Kesehatan. Jakarta: Rineka Cipta.
Nursalam. (2011). Manajemen Keperawatan : Aplikasi Dalam Praktik Keperawatan Profesional. Jakarta: Salemba Medika.

Nursalam and Efendi. (2008). Pendidikan dalam Keperawatan. Jakarta: Salemba Medika.

Nurrahmah, I. (2003). Peran dan Fungsi Pembimbing Praktek Klinik Keperawatan. Makalah disajikan dalam Pelatihan SDM Lahan Praktek dan Institusi Diknakes Propinsi Jawa Timur. Murnajati Lawang, 13 Oktober Potter, P. A., and Perry, A. G. (2011). Fundamental Keperawatan: buku 2 edisi 7. Jakarta: Salemba Medika.

Reilly, D. E., and Obermann, M. H. (2002). Pengajaran Klinis Dalam Pendidikan Keperawatan Edisi 2. Jakarta: EGC.

Schunk, D. H. (2008). Learning theories: an educational perspective $5^{\text {th }} \mathrm{ed}$. New York: Macmillan Publishing Company.

Slavin, R. E. (2009). Educational Psychology: Theory and Practice $9^{\text {th }}$ ed. Boston: Allyn and Bacon.

Suciati. (2006). Taksonomi Tujuan Insruksional. Jakarta: Buku Acuan Program Pekerti P2P Universitas Negeri Jakarta.

Suherman. (2009). Metode Bimbingan Klinik Keperawatan. Makalah disajikan dalam Pelatihan Bimbingan Klinik Keperawatan Nasional. Malang. Politehnik Kesehatan Malang. 25-28 Februari.

Sujana. (2009). Penilaian Hasil Proses Belajar Mengajar. Jakarta: PT Raja Grafindo Persada.

Sujarwadi, M. (2005). Pengaruh Metode Bedsite Teaching dan Demonstrasi Terhadap Peningkatan Ketrampilan Pemeriksaan Fisik Mahasiswa di Akademi Keperawatan Pemkot Pasuruan. Tugas Akhir tidak diterbitkan. Surabaya: Fakultas Ilmu Keperawatan Universitas Airlangga Surabaya. 
Sunaryo. (2004). Psikologi Untuk Keperawatan. Jakarta: EGC.

Suparno, P. (2001). Filsafat Konstruktivisme dalam Pendidikan. Jogjakarta: Kanisius.

Taylor, C., Lillis, C., and Mone, P. L. (2010). Fundamental of Nursing, The Art and Science of Nursing Care. LWW: Seventh, North American Edition.

Widodo, A. (2005). Taksonomi Tujuan Pembelajaran. Retrieved from http://file.upi.edu/Direktori/ DFPMIPA/JUR.PEND.BIOLOGI/196 705271992031ARIWIDODO/2005RevisiTaksonomiBloom-Didaktis.pdf on October 25, 2010.

Cite This Article As: Zuhriodah, I., Huda, N., \& Cahyono, B. D. The Effect of Clinical Teaching Method and Learning Style on Clinical Nursing Learning Outcomes. Nurse and Health: Jurnal Keperawatan 2019; 8(2): 108114. 